\title{
Implementasi Metode Top Down Parsing pada Teknologi Bahasa Alamiah dalam Bentuk Chatbot YOULLIA INDRAWATY, YANDRI HARIANJA
}

\author{
JurusanTeknikInformatika, Fakultas Teknik Industri \\ Institut Teknologi Nasional Bandung
}

Email: youllia@itenas.ac.id

\begin{abstract}
ABSTRAK
Chatbot adalah sebuah program komputer yang dirancang untuk mensimulasikan sebuah percakapan yang interaktif kepada user dalam bentuk teks. Chatbot dibangun dengan menggunakan metode top down parsing. Top down parsing digunakan untuk mencari kesimpulan dari pertanyaan user yang terdapat dalam database. Kemudian sistem akan mencari kata kunci berdasarkan pertanyaan user. Setelah kata kunci ditemukan maka akan dicocokan dengan kata kunci yang terdapat dalam database. Kemudian sistem akan menampilkan jawaban yang sesuai dengan kata kunci yang terdapat dalam database. Hasil pengujian black box pada proses tanya jawab, sistem dapat menjawab masukan dari pengguna dengan baik sesuai dengan kata kunci yang ada di database. Hasil pengujian user acceptance test tanya jawab yang diajukan langsung kepada 10 mahasiswa, 70\% chatbot mudah dioperasikan, 40\% chatbot menarik bagi mahasiswa, dan 70\% chatbot bermanfaat bagi mahasiswa untuk mendapatkan informasi yang diinginkan.
\end{abstract}

\begin{abstract}
Chatbot is a computer program designed to simulate an interactive conversation to the user in text form. Chatbot built using top down parsing. Top down parsing is used to find the conclusion of user questions contained in database. Then the system will search for keywords based on user questions. After the keywords are found then it will be matched with the keywords contained in database. Then the system will display the appropriate answers to the keywords contained in database. Black box testing results in the process of questioning answering system can answer with good input from the user according to the key words in database. The results of testing the user acceptance test questions and answers are submitted directly to 10 students, $70 \%$ chatbot easy to operated, $40 \%$ chatbot attractive to students, and chatbot useful for students to get needed.
\end{abstract}

Keyword: Chatbot, Top Down Parsing, Database 


\section{PENDAHULUAN}

Chatbot adalah sebuah program komputer yang dirancang untuk mensimulasikan sebuah percakapan atau komunikasi yang interaktif kepada user (manusia) melalui bentuk teks, suara, dan atau visual. Percakapan yang terjadi antara komputer dengan manusia merupakan bentuk respon dari program yang telah dideklarasikan pada database program pada komputer. Respon yang dihasilkan merupakan hasil pemindaian kata kunci pada kalimat masukanuser dan menghasilkan respon balasan yang dianggap paling cocok, atau pola kata-kata yang dianggap paling mendekati pola kata-kata yang terdapat di database.

Chatbot dibangun dengan menerapkan teknologi bahasa alamiah dengan menggunakan metodetop down parsing. Metode top down parsingmerupakan sebuah proses yang menguraikan sebuah kalimat mulai dari constituent terbesar sampai menjadi constituent terkecil sampai semua komponen yang dihasilkan adalah constituent terkecil dalam kalimat berupa kata. Top down parsing digunakan untuk mencari kesimpulan dari pertanyaan user yang terdapat dalam database.Kemudian sistem akan mencari kata kunci berdasarkan pertanyaan user. Setelah kata kunci ditemukan maka akan dicocokan dengan kata kunci yang terdapat dalam database. Kemudian sistem akan menampilkan jawaban yang sesuai dengan kata kunci yang terdapat dalam database.

Pada sistem ini percakapan dilakukan dalam Bahasa Indonesia yang sesuai dengan Ejaan Yang Disempurnakan(EYD), jawaban pertanyaan dari user hanya berupa teks kalimat. Kalimat masukan berupa pertanyaan dengan menggunakan kata tanya.

\section{METODOLOGI PENELITIAN}

\subsection{Chatbot}

Chatbot adalah sebuah program komputer yang dirancang untuk mensimulasikan sebuah percakapan atau komunikasi yang interaktif kepada user (manusia) melalui bentuk teks, suara, dan atau visual. Percakapan yang terjadi antara komputer dengan manusia merupakan bentuk respon dari program yang telah dideklarasikan pada database program pada komputer. Respon yang dihasilkan merupakan hasil pemindaian kata kunci pada masukanuser dan menghasilkan respon balasan yang dianggap paling cocok, atau pola kata-kata yang dianggap paling mendekati dengan kata kunci yang terdapat di database. Chatbot mampu meniru komunikasi manusia. Jika manusia sedang melakukan percakapan dengan program ini, seakan-akan ada 2 pribadi manusia yang saling berkomunikasi. Nyatanya, manusia berkomunikasi dengan Bot. Bot adalah program yang dirancang untuk merespon segala jenis pertanyaan dan pernyataan berdasarkan kalimat masukan dari user. Hal ini dapat dilakukan karena sebelumnya sudah dideklarasikan pada database, berupa entitas-entitas kata, pola kalimat, dan berbagai jenis pernyataan dan pertanyaan [1].

\subsection{Bahasa Alamiah (Natural Language)}

Bahasa alami adalah suatu bentuk representasi dari suatu pesan yang ingin dikomunikasikan antar manusia. Bentuk utama representasinya adalah berupa suara atau ucapan (spoken language), tetapi sering pula dinyatakan dalam bentuk tulisan.Bahasa dapat dibedakan menjadi (1) Bahasa Alami, dan (2) Bahasa Buatan. Bahasa alami adalah bahasa yang biasa digunakan untuk berkomunikasi antar manusia, misalnya bahasa Indonesia, Sunda, Jawa, Inggris, Jepang, dan sebagainya.Bahasa buatan adalah bahasa yang dibuat secara khusus untuk memenuhi kebutuhan tertentu, misalnya bahasa pemodelan atau bahasa pemrograman 
komputer [2]. Gambaran organisasi dari sebuah sistem Natural Processing Language yang lengkap ditunjukkan pada Gambar 1.

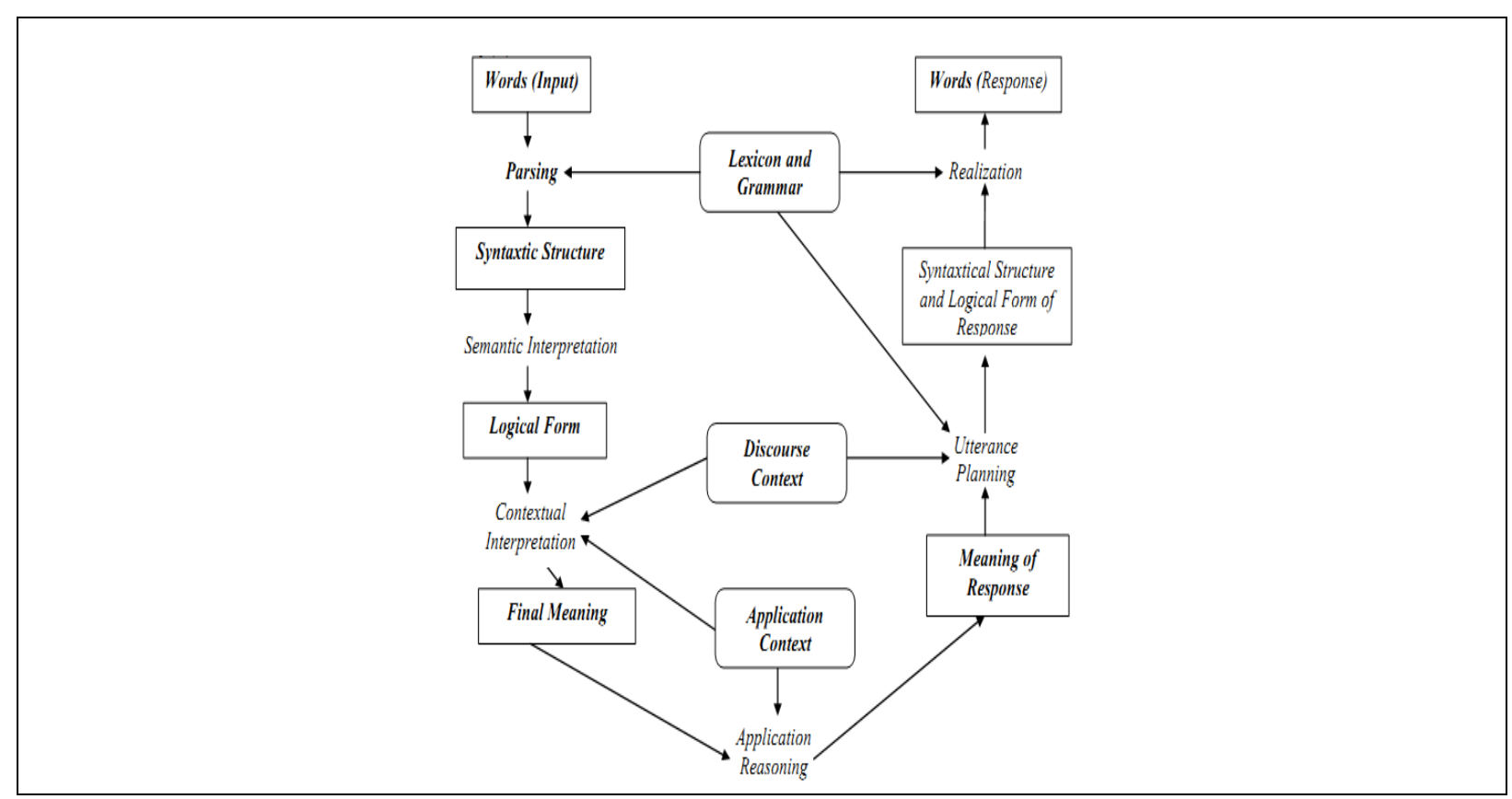

\section{Gambar 1. Organisasi Sebuah Sistem NLP}

(Sumber : Fendy Ridwan, 2012)

\subsection{Gramatika}

Tata bahasa dalam bahasa alami menspesifikasikan struktur kalimat yang berfungsi untuk menentukan kategori sintaksis dasar seperti kata benda dan kata kerja, dan menentukan struktur dari kalimat dan tata bahasa. Dalam bahasa alami, kalimat tidaklah sering di parsing untuk mengetahui apakah kalimat tersebut benar atau tidak. Parsing digunakan untuk menentukan struktur dan membantu mencari arti dari sebuah kalimat. Tetapi kebanyakan tata bahasa mengacu pada pengaturan bahasa yang resmi, bila menggunakan kalimat dengan bahasa yang telah dimodifikasi, parsingakan menjadi semakin rumit [2]. Berikut merupakan aturan tata bahasa seperti pada Gambar 2.

Kalimat $\longrightarrow$ Frase_kata benda, Frase_kata kerja

\section{Gambar 2. Aturan Parsing \\ Sumber : (Astari kartika hadinata dan Novita, 2007)}

Dari keterangan Gambar 2 dapat dijelaskan bahwa jika kita memiliki sebuah frase_kata benda, yang diikuti oleh sebuah frase_ kata kerja maka kita memiliki sebuah kalimat

\subsection{Parsing}

Parsing atau syntactic analyzer pada kompilator bahasa pemrograman berfungsi untuk memeriksa kebenaran kemunculan setiap kalimat. Proses parsing membagi-bagi kalimat menjadi kata per kata. Pada sistem tanya jawab, fungsi dari parsing berbeda karena kalimat yang akan diolah memiliki tipe yang sama yaitu berupa kata [3]. Urutan kemunculan kata akan diolah dengan mengacu pada database agar didapatkan makna kalimat yang sesungguhnya. Proses parsing menentukan pembuatan frase untuk kata, seperti kata_kerja, kata_keterangan, kata_benda, dan seterusnya. 


\subsection{Top Down Parsing}

Top down parsing bekerja dengan cara menguraikan sebuah kalimat mulai dari constituent yang terbesar sampai menjadi constituent yang terkecil. Hal ini dilakukan terus-menerus sampai semua komponen yang dihasilkan ialah constituent terkecil dalam kalimat yaitu kata [3]. Berikut merupakan contoh proses top down parsingseperti pada Gambar 3.

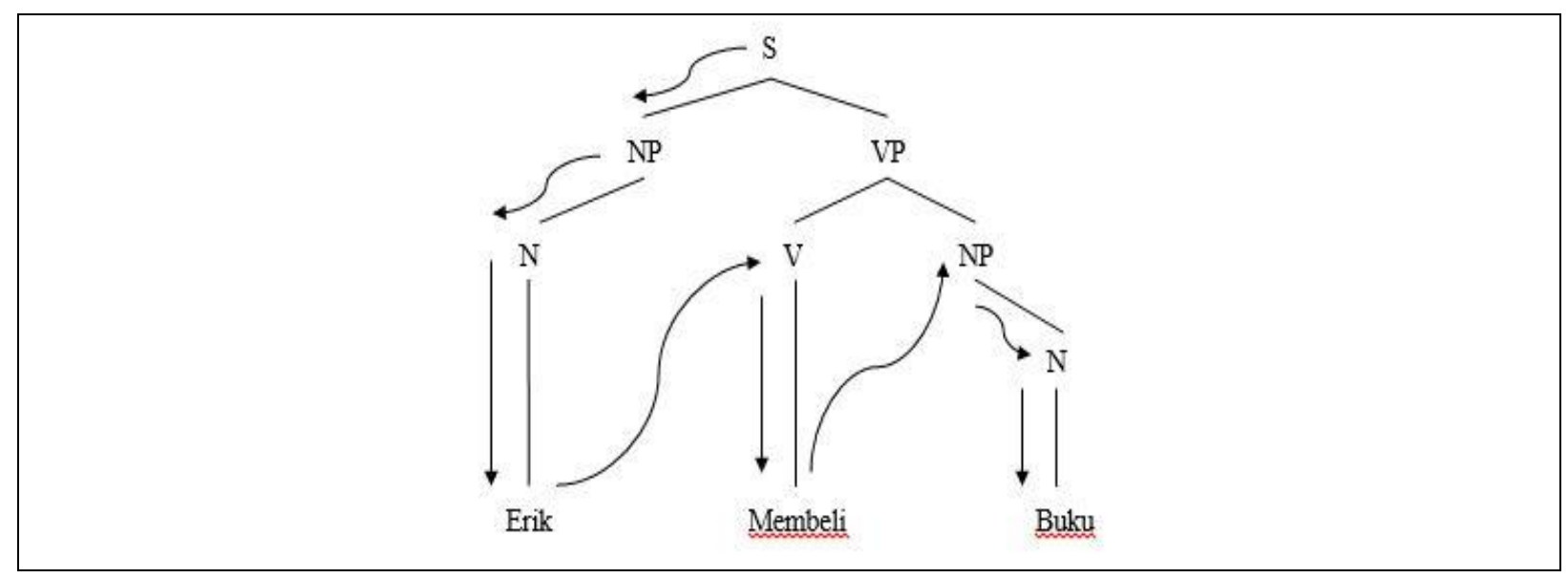

Gambar 3. Top down parsing

Sumber: (James Suciadi, 2001)

Proses top down parsing pada Gambar 3 dapat dijelaskan sebagai berikut:

$$
\begin{aligned}
\text { Keterangan: } S & =\text { Kalimat (proses awal) } \\
N P & =\text { Frase_kata benda } \\
V P & =\text { Frase_kata kerja } \\
S & =\text { Subjek } \\
V & =\text { Kata kerja } \\
N & =\text { Kata benda }
\end{aligned}
$$

\section{ANALISIS DAN PEMBAHASAN}

\subsection{Perancangan aplikasi chatbot}

Proses flowchart aplikasi chatbot dimulai dengan user memasukan kalimatpertanyaan. Kemudian kalimat pertanyaan tersebut dibagi menjadi beberapa kata dalam proses parsing. Setelah kalimat pertanyaan di parsing akan dilakukan proses SPOK. Dalam proses SPOK akan dilakukan pengecekan jenis kata dari kalimat pertanyaan hasil parsing. Kemudian hasil dari SPOK akan dicari kata kunci yang sesuai dengan kata kunci yang ada pada databasechatbot. Apabila kata kunci ditemukan maka sistem akanmelakukan proses reasoningsedangkan jika sistem tidak dapat menemukan kata kunci maka jawaban yang muncul tidak berhubungan dengan pertanyaan user.Dalam proses reasoning sistem akanmenjawab pertanyaan user dengan jawaban reasoningBerikut merupakan proses flowchart aplikasichatbot seperti pada Gambar 4. 


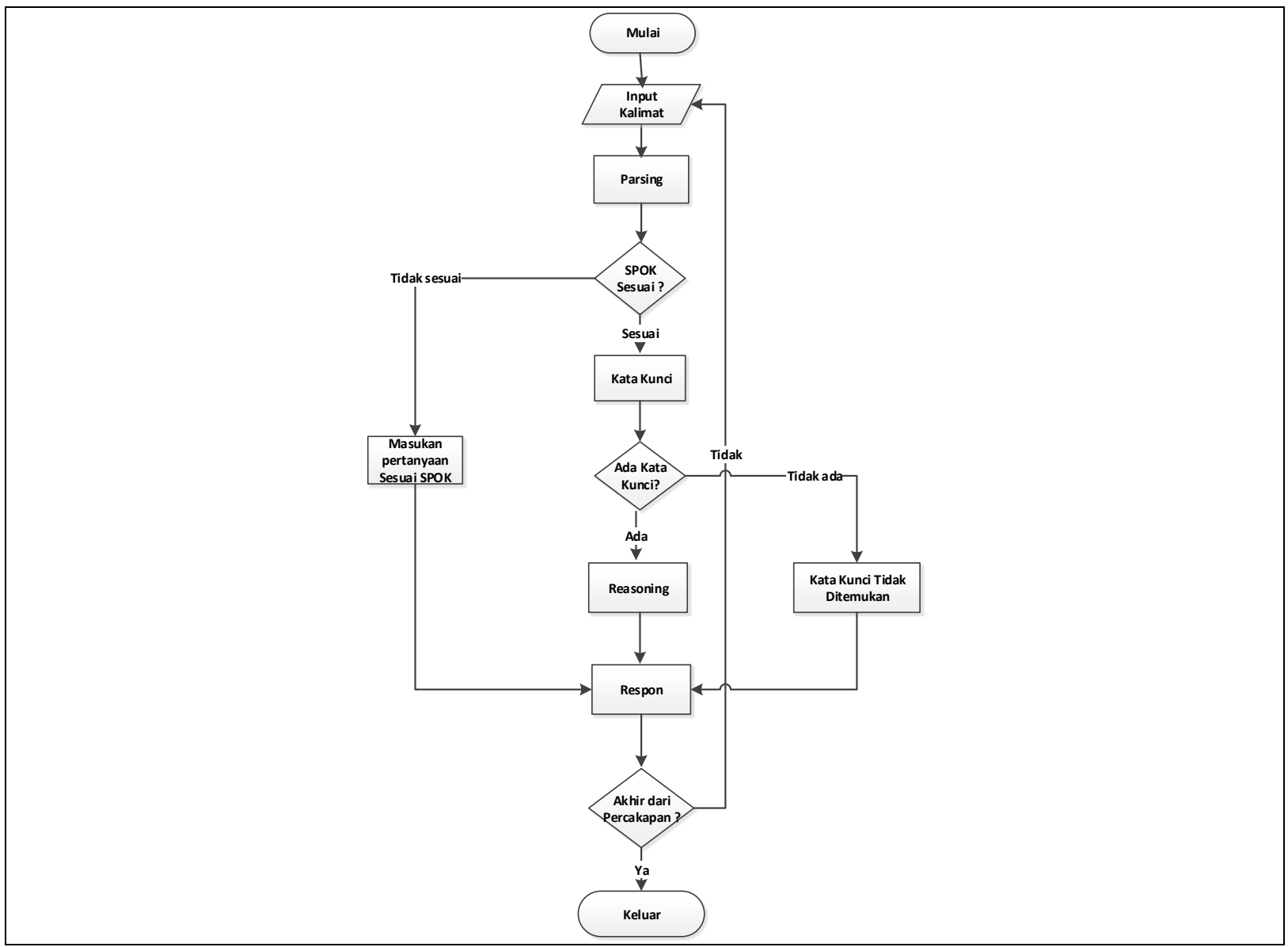

\section{Gambar 4. Flowchart aplikasi chatbot \\ Sumber : (Astari kartika hadinata dan Novita, 2007)}

\subsection{Proses Kalimat Masukan}

Proses pendeteksian kalimat masukan yaitu dengan mengenali input yang dimasukan oleh user dan memasukannya kedalam variabel penampung untuk kemudian dibagi-bagi ke dalam kelompok variable kata.

publicstring InputKalimat

\{

get $\{$ return inputKalimat; $\}$

set $\{$ inputKalimat $=$ value; $\}$

\}

Pada proses ini kalimat masukan dari user adalah kalimat pertanyaan yaitu: "Siapa yang mengajar matakuliah logika fuzzy?". Kemudian kalimat pertanyaan diproses secara parsing.

\subsection{Proses Parsing}

Pada proses ini, kalimat masukan yang diterima diubah menjadi huruf kecil dan semua tanda baca (titik, koma, kutip, garis miring, dan tanda seru) diubah menjadi spasi. Kemudian kalimat masukan dipecah menjadi kata per kata dan dimasukan kedalam satu variabel penampung kata untuk selanjutnya menentukan jenis kata dalam proses SPOK.Proses parsingakan dijelaskan sebagai berikut: 


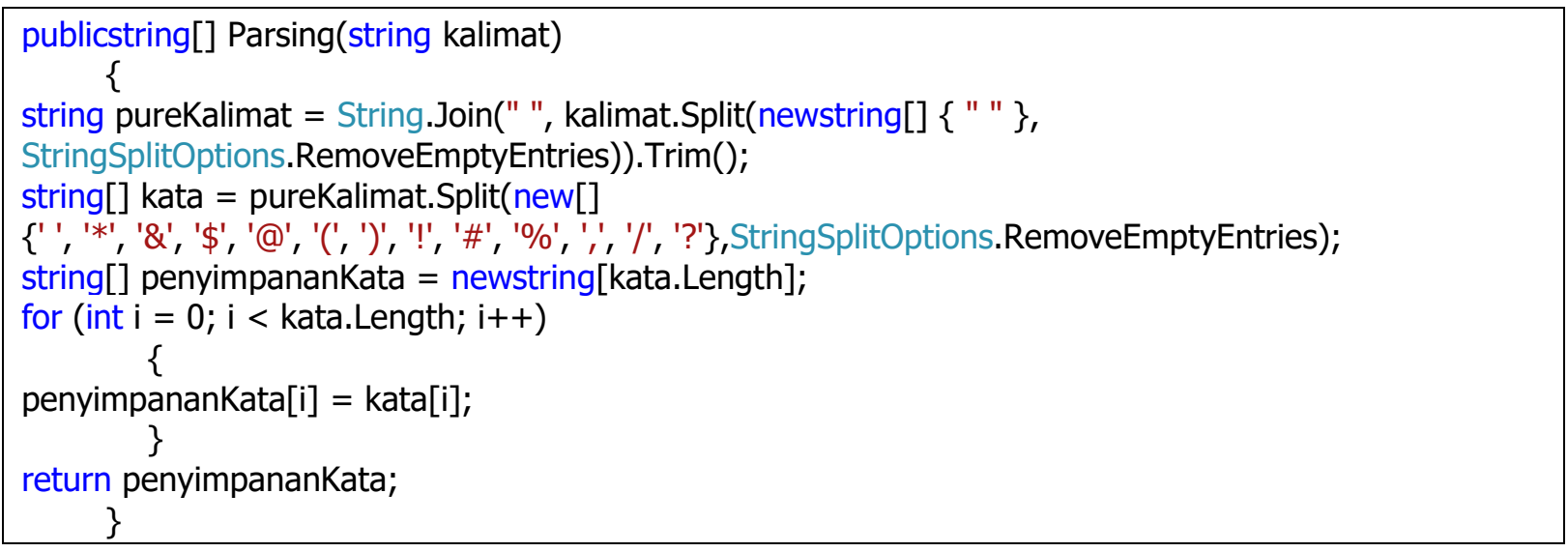

Proses ini menjelaskan jika ada kalimat pertanyaan yang dimulai dengan multiple spacediantara kata, sebelum dan sesudah kalimat. Maka dilakukan proses penghilangan multiple space menjadi normal space. Setelah itu proses dilanjutkan dengan menghilangkan karakter khusus seperti: '*', '@' , '\$', '\#',

dll. Kemudian akan dilakukan proses pemecahan kalimat menjadi kata dan menyimpan kata ke dalam variabel penyimpanan kata.

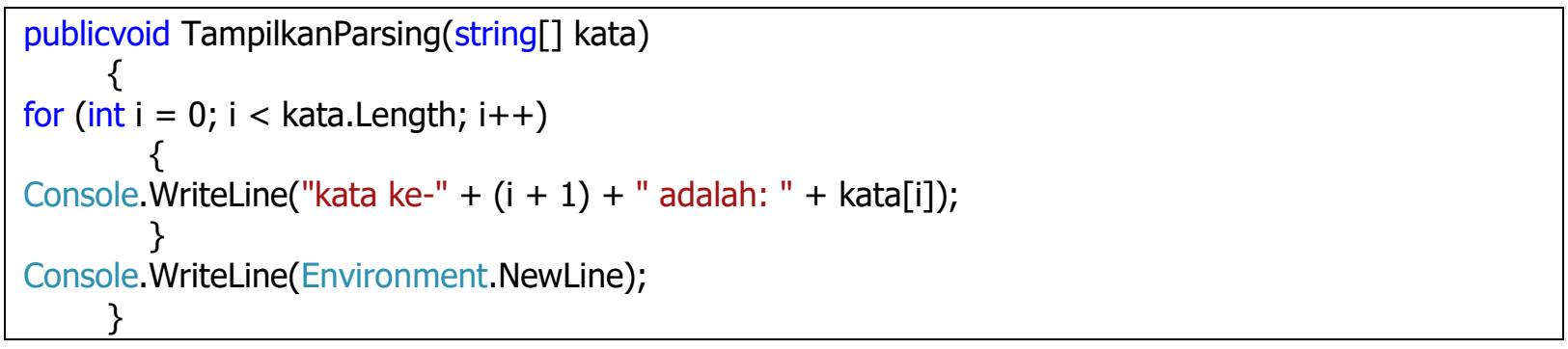

Proses ini menampilkan hasil parsingkalimat pertanyaan berupa kata. Kata yang ditampilkan dari proses ini sebagai berikut:

siapayangmengajarmatakuliah

logikafuzzy

\subsection{Proses SPOK}

Pada proses SPOK dilakukan pengecekan jenis kata yang merupakan hasil dari proses parsing. Berikut proses SPOK dari hasil proses parsing kalimat masukan pengguna.

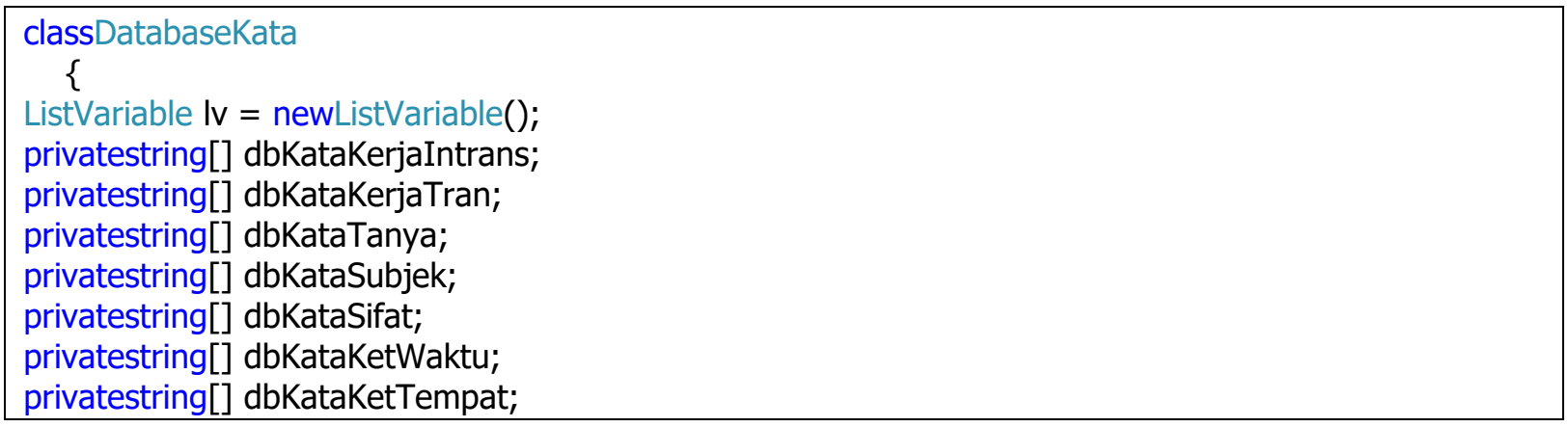




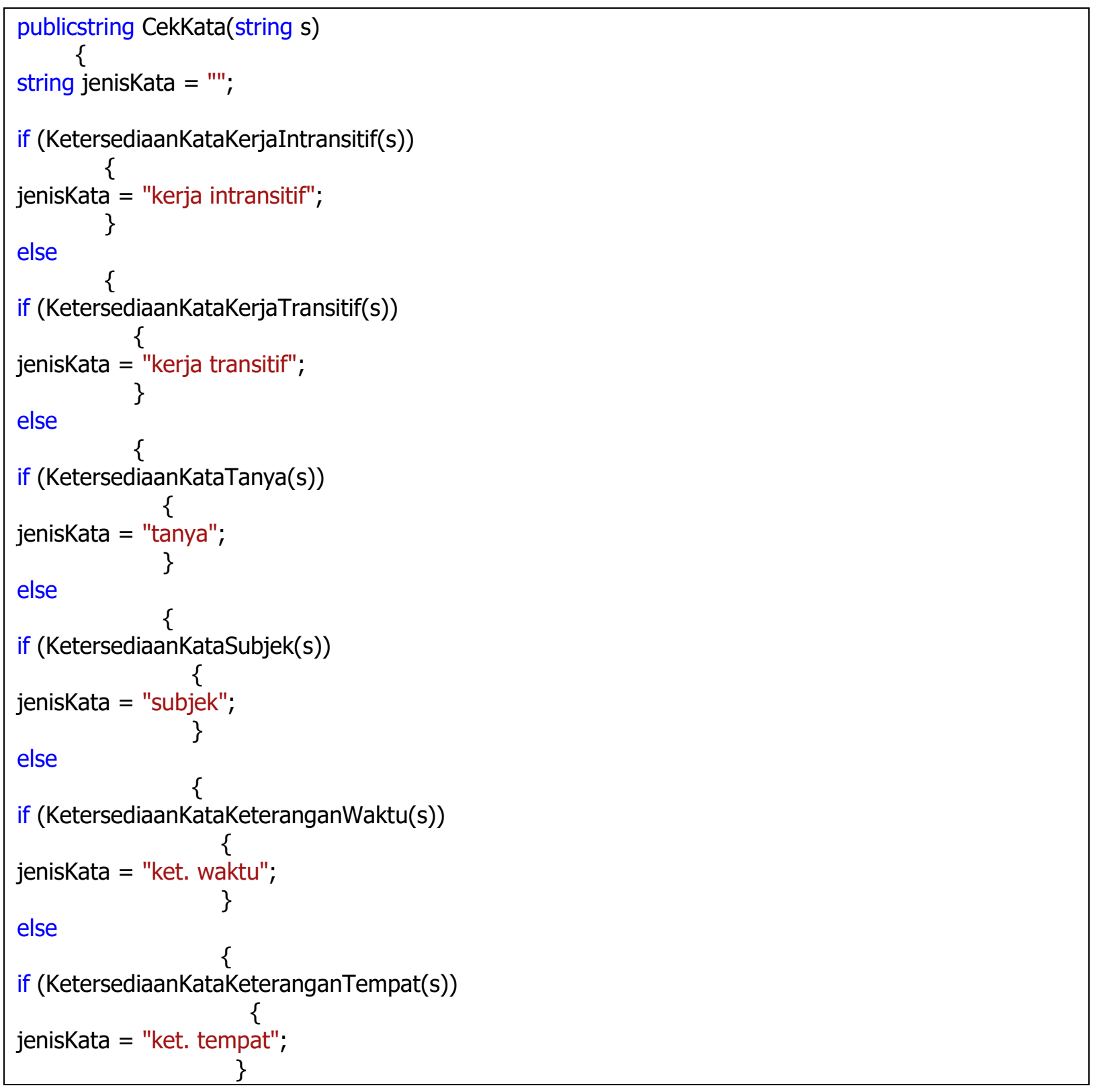

Pada proses ini dilakukan pengecekan jenis kata dari hasil parsingseperti kata_kerja transitif, kata kerja intransitif, kata tanya , kata subjek, kata keterangan waktu, kata keterangan tempatdll, dan disesuaikan dengan jenis kata yang terdapat dalam databasechatbot.Sehingga didapatkan dari proses SPOK sebagai berikut :

Siapa = Kata tanya

yang $=$ Kata sambung

mengajar = Kata kerja transitif

matakuliah $=$ Kata benda

logika fuzzy $=$ Kata benda

\subsection{Proses Kata Kunci}

Kata kunci digunakan untuk mengidentifikasi topik yang sedang dibicarakan oleh user. Proses kata kunci ditujukan untuk menemukan jawaban atas masukan yang diberikan pengguna. 
Setelah kata kunci diketahui, sistem dapat langsung memberikan respon terhadap masukan dari user.Apabila kata kunci tidak ditemukan program akan memberikan respon kata kunci tidak ditemukan.

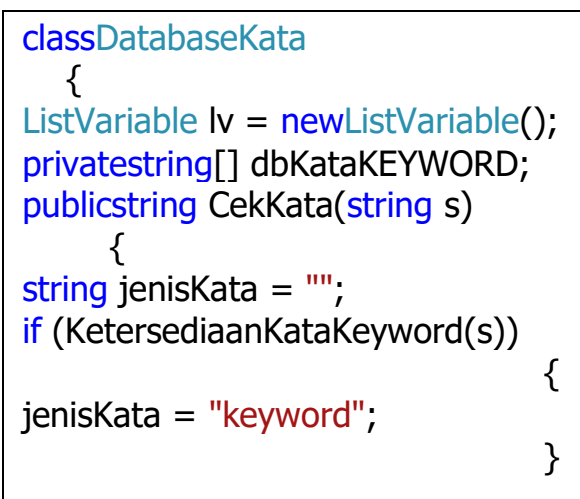

Pada kalimat masukan "Siapa yang mengajar matakuliah logika fuzzy?"ditemukan kata kunci yaitu :"mengajar matakuliah nama_mk". Kata kunci tersebut terdapat dalam database chatbot.

\subsection{Proses Respon Jawaban}

Proses reasoning dilakukan apabila kata kunci yang terdapat dalam knowledge basechatbot diketahui. Kemudian dilakukan proses pengembalian respon jawaban kepada pengguna.

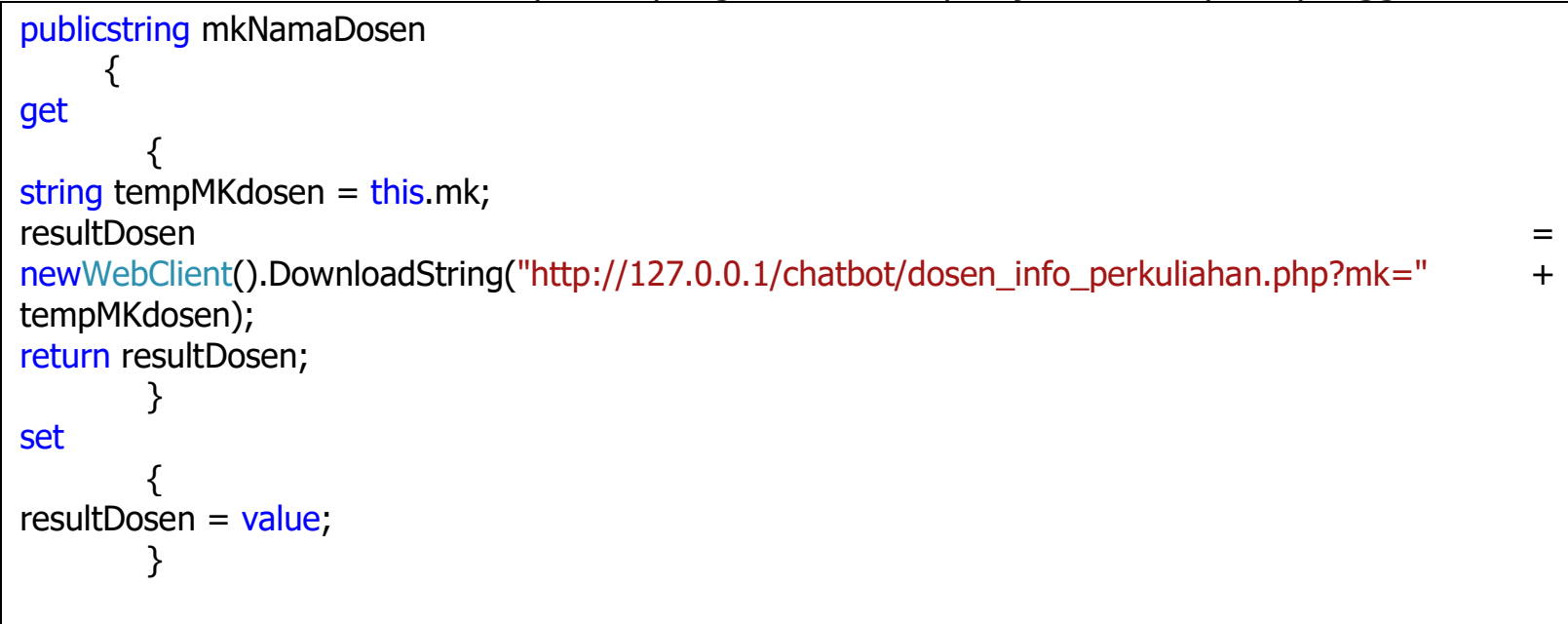

Proses kata kunci "mengajar matakuliah nama_mk"mengacu pada respon jawaban tentang nama dosen matakuliah. Karena kata kunci tersebut berhubungan dengan nama dosen matakuliah yang terdapat pada database chatbot. Sehingga respon jawaban yang dihasilkan adalah "dosen yang mengajar matakuliah logika fuzzy adalah nama_dosen".

\subsection{Kesimpulan Top Down Parsing}

Top down parsing memulai pemeriksaan dari simbol awal kalimat dan mencoba untuk mencari bentuk simbol terminal berikutnya yang sesuai dengan jenis kata dari kalimat masukan. Proses top down parsingdapat dilihat pada Gambar 5. 


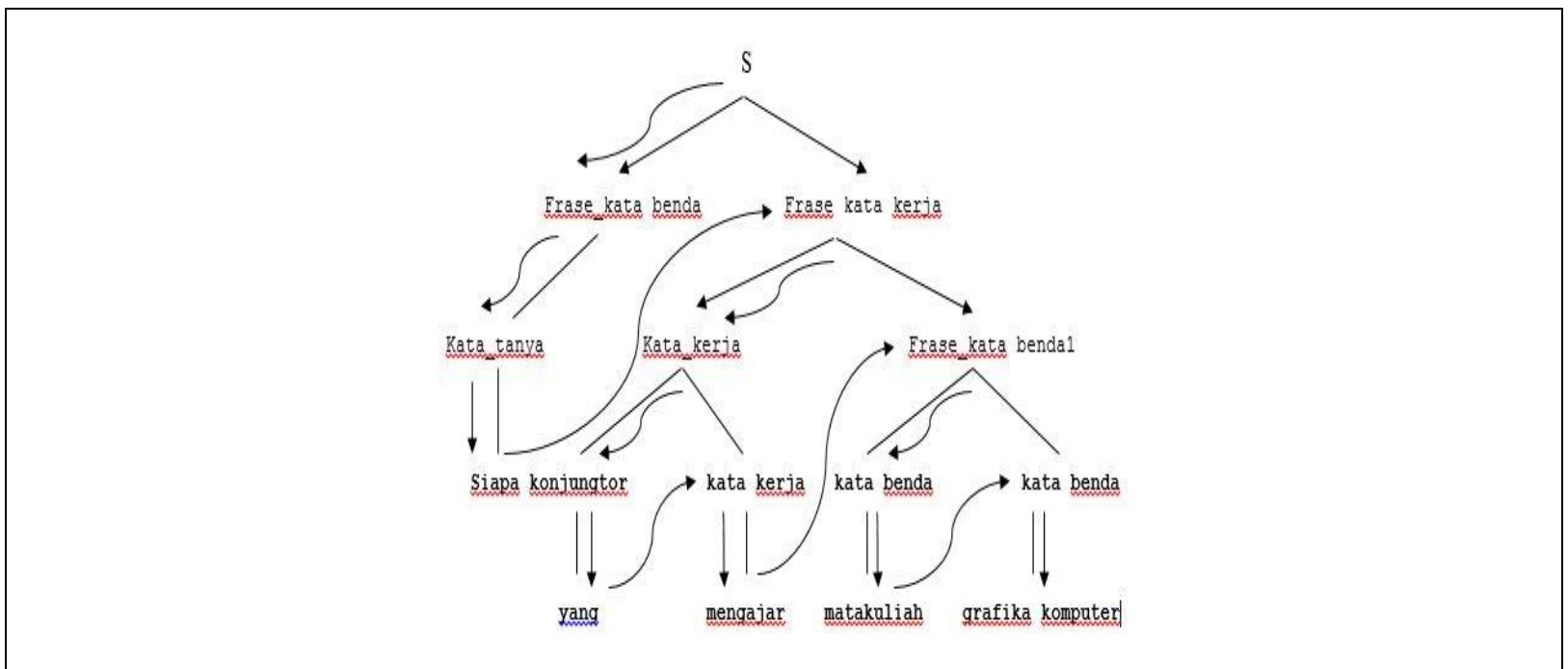

Gambar 5. Top down parsing

Pada Gambar 5 ini dijelaskan proses top down parsing dengan menggunakan aturan tata bahasa Indonesia.

Kalimat awal:

"siapa yang mengajar matakuliah grafika komputer ?"

Tahapan selanjutnya adalah menentukan jenis kata dari kalimat dan menghasilkan kata. Adapun jenis kata yang dihasilkan adalah sebagai berikut :

$$
\begin{aligned}
& \text { siapa = kata tanya } \\
& \text { yang = kata sambung } \\
& \text { mengajar = kata kerja transitif } \\
& \text { matakuliah = kata benda } \\
& \text { grafika komputer = kata benda }
\end{aligned}
$$

Kemudian akan dilakukan proses top down parsing dengan aturan tata bahasa indonesia.

Kalimat $\longrightarrow$ Frase_kata benda, Frase_kata kerja

$\mathrm{S}$ = Frase_kata benda, Frase_kata kerja

Frase_kata benda $=$ kata_tanya

Kata tanya $=$ Siapa

Frase_kata kerja = kata kerja, Frase_kata benda

Kata kerja $=$ konjungtor, kata kerja

Konjungtor $=$ yang

Kata kerja $=$ mengajar

Frase_kata benda $=$ kata benda, pelengkap

Kata benda $=$ matakuliah

Pelengkap $=$ grafika komputer

Dari proses top down parsing diperoleh struktur kalimat yang benar yaitu :

"Siapa yang megajar matakuliah grafika komputer" 
Setelah strukur kalimat diketahui, sistem mencari kata kunci dari setiap masukan.Apabila sistem menemukan kata kunci tersebut maka kata kunci dicocokan dengan kata kunci yang terdapat dalam database. Kemudian sistem merespon kalimat masukan pengguna berdasarkan kata kunci yang terdapat dalam database dan menampilkan jawaban yang sesuai dengan kata kunci tersebut.

\subsection{Percakapan}

Pengujian ini dilakukan untuk menampilkan halaman percakapan. Kemudian dihalaman percakapan kita dapat melakukan tanyajawab seputar informasi akademik. Pengujian percakapan dapat dilihat pada Gambar 6.

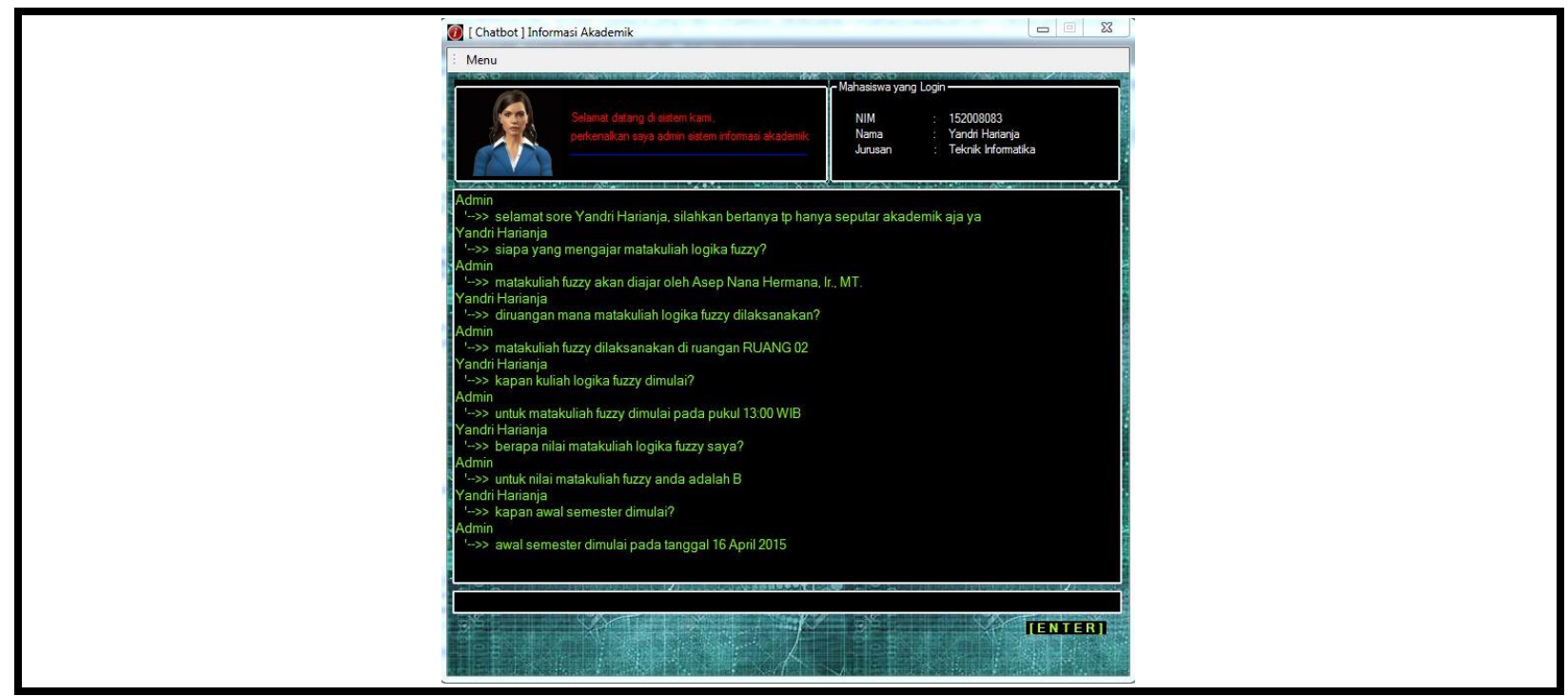

Gambar 6. Pengujian percakapan

\subsection{Pengujian beta}

Pengujian ini menggunakan kuisioner yang terdiri dari 5 pertanyaan yang ditanyakan kepada 10 responden. Berdasarkan hasil dari jawaban yang diberikan oleh responden yang telah menggunakan aplikasi chatbot dapat ditarik kesimpulan bahwa aplikasi chatbot sebesar $70 \%$ mudah dioperasikan, $60 \%$ aplikasi chatbot mempermudah mahasiswa dalam mencari informasi seputar jurusan informatika, $40 \%$ aplikasi chatbot menarik bagi mahasiswa, dan $70 \%$ aplikasi chatbot bermanfaat bagi mahasiswa untuk mendapatkan informasi yang diinginkan.

\section{KESIMPULAN}

Berdasarkan hasil pengujian black box pada proses tanya jawab sistem dapat menjawab masukan dari pengguna dengan baik sesuai dengan kata kunci yang ada di knowledge base. Dan hasil pengujian user acceptance test tanya jawab yang diajukan langsung kepada mahasiswa, 70\% aplikasi chatbot mudah dioperasikan, 60\% aplikasi chatbot mempermudah mahasiswa dalam mencari informasi seputar jurusan informatika, 40\% aplikasi chatbot menarik bagi mahasiswa, dan $70 \%$ aplikasi chatbot bermanfaat bagi mahasiswa untuk mendapatkan informasi seputar jurusan teknik informatika. 
Implementasi Metode Top Down Parsing pada Teknologi Bahasa Alamiah dalam Bentuk Chatbot

\section{DAFTAR RUJUKAN}

[1] Kristanto,Andri (2005). Kecerdasan Buatan. Graha Ilmu, Yogyakarta.

[2] Hasugian, Jonner (2006). Penggunaan Bahasa Alamiah dan Kosa kata Terkendali dalam

[3] Sistem Temu Balik Informasi Berbasis Teks. Unversitas Sumatera Utara, Sumatera Utara.

[4] Suciadi, James (2001). Studi analisis Metode-metode Parsing dan Interpretasi Semantik pada Natural Language Processing. Universitas Kristen Petra. Surabaya.

[5] Fatima, Choirunnisa (2013). Pencocokan String pada Aplikasi Chatbot Sederhana. Institut Teknologi Bandung. Bandung. 